\title{
Screening for Panton-Valentine Leukocidin Toxin Genes in Multi-Drug Resistant Methicillin-Resistant Staphylococcus aureus Nasal Isolates from Healthy School Children in Mariental, Namibia
}

\author{
Sunette Walter*, Ronnie Böck \\ Biological Sciences Department, University of Namibia, Windhoek, Namibia \\ Email: *sunette.walter8@gmail.com
}

How to cite this paper: Walter, S. and Böck, R. (2020) Screening for Panton-Valentine Leukocidin Toxin Genes in Multi-Drug Resistant Methicillin-Resistant Staphylococcus aureus Nasal Isolates from Healthy School Children in Mariental, Namibia. Journal of Biosciences and Medicines, 8, 13-19. https://doi.org/10.4236/jbm.2020.812002

Received: October 21, 2020

Accepted: December 7, 2020

Published: December 10, 2020

Copyright $\odot 2020$ by author(s) and Scientific Research Publishing Inc. This work is licensed under the Creative Commons Attribution International License (CC BY 4.0).

http://creativecommons.org/licenses/by/4.0/

\begin{abstract}
Panton-Valentine leukocidin (PVL) is one of the toxins responsible for increased virulence of Staphylococcus aureus. In school settings where children are in close contact with each other, $S$. aureus strains, including those that may produce PVL, can be transmitted and spread in the community. Twenty-two multi-drug resistant MRSA nasal isolates from children enrolled in five schools in the town of Mariental and the multi-drug resistant American Type Culture Collection MRSA reference strain $S$. aureus ATCC 33591 (PVL-negative control) were used for molecular assays. Plasmid deoxyribonucleic acid (DNA) of isolates was amplified by polymerase chain reaction (PCR) and amplified PCR products were electrophoresed on a $2.5 \%(\mathrm{w} / \mathrm{v})$ agarose gel containing $12 \mu \mathrm{l} 0.5 \mu \mathrm{g} / \mathrm{ml}$ ethidium bromide and $1 \times \mathrm{TAE}$ (Tris-acetate-EDTA) buffer at 90 volts for 50 minutes. The developed gel was viewed for the PVL-associated lukS and lukF genes that amplified at $151 \mathrm{bp}$ and $406 \mathrm{bp}$, respectively. Our results indicated that seven nasal isolates had PVL toxin gene(s). From the seven isolates, three were tested positive for both lukS and lukFgenes, one tested positive for only lukS, and three tested positive for only $l u k F$. Two of the isolates harbouring both $l u k S$ and $l u k F$ genes shared the same antibiotic resistance pattern and one of them could also produce enterotoxin A. One of the isolates with only lukF gene could produce enterotoxins $\mathrm{B}$ and $\mathrm{C}$. These toxin-producing isolates can be expected to be more virulent than non-producers. Children should be educated on the importance of regular handwashing with soap and water to prevent the spread of potentially virulent staphylococci amongst them and the wider community. This work warrants a larger study to be carried out to investigate PVL toxin and its associated infections in Staphylococcus from school children in
\end{abstract}


Namibia.

\section{Keywords}

Methicillin-Resistant Staphylococcus aureus, Panton-Valentine Leukocidin, Children

\section{Introduction}

Staphylococcus can asymptomatically colonize humans and most people have staphylococci as commensals of the skin and upper respiratory tract [1]. Infections can occur when colonizing strains enter normally sterile sites in the body through damaged skin or mucosal surfaces [2]. The human nasal cavity contains Staphylococcus aureus as normal microflora [3] and predisposes one to potential self-infection [4] by these opportunistic pathogens [5]. Reid et al. (2017) [6] regard nasal carriage of $S$. aureus as a major risk factor for becoming infected with this bacterium which is considered the most virulent of all staphylococcal species [2].

Healthy school children under 16 years are potential carriers of $S$. aureus, especially methicillin-resistant $S$. aureus (MRSA) and multi-drug resistant strains [7]. Methicillin-resistant $S$. aureus is resistant to beta-lactam antibiotics, while some strains are multi-drug resistant and may produce disease-causing toxins. Drug resistant strains are often responsible for chronic, persistent and recurrent infections. One of the toxins responsible for increased virulence of $S$. aureus is Panton-Valentine leukocidin (PVL). According to Brooks et al. (2013) [1] PVL toxin can kill human and rabbit white blood cells. Two components of the toxin, namely $\mathrm{S}$ and $\mathrm{F}$, act synergistically on the white cell membrane to accomplish this [1].

In school settings where children are in close contact with each other, $S$. aureus strains (including community-associated MRSA) that may produce PVL, can be transmitted and spread in the community [8] [9]. Staphylococci from an asymptomatic carrier or diseased person can be released from the respiratory tract, transmitted by the hands, or transported in or on living and non-living objects. Cleanliness, hygiene and aseptic management of wounds are effective ways to control staphylococcal infections [5]. Handwashing in particular is very important in disease control [1].

Based on the recommendations of a doctoral study [10] this work aimed to screen multi-drug resistant MRSA nasal isolates obtained from healthy school children for PVL genes.

\section{Materials and Methods}

\subsection{Growth of Bacterial Cultures for Deoxyribonucleic Acid Extraction}

Twenty-two multi-drug resistant MRSA nasal isolates from healthy children 
enrolled in five schools in the town of Mariental and the multi-drug resistant MRSA reference strain $S$. aureus ATCC 33591 (PVL-negative control) were used for molecular assays. Based on the protocol provided in the QuickLyse Miniprep Kit (Qiagen, Germany) that we used, cultures preserved in glycerol were streaked out on tryptic soy agar plates and incubated at $37^{\circ} \mathrm{C}$ for 18 hours. A single colony from each agar plate was inoculated into $50 \mathrm{ml}$ falcon centrifuge tubes each containing $3 \mathrm{ml}$ Luria-Bertani (LB) broth and a $30 \mu \mathrm{g}$ cefoxitin antibiotic disc. These were then incubated for only 15 hours to prevent cultures from reaching the stationary phase of growth. Prolonged incubation could result in lysis of cells and reduced plasmid yields. After incubation, the broth cultures were vortexed to mix them properly.

\subsection{Plasmid Deoxyribonucleic Acid Isolation from Bacterial Cultures}

A QuickLyse Miniprep Kit (Qiagen, Germany) was used to extract plasmid deoxyribonucleic acid (DNA) from isolates, according to the protocol in the kit: Using a $2 \mathrm{ml}$ QuickLyse Lysis Tube, bacterial cells were pelleted from $1.5 \mathrm{ml}$ culture $\left(\mathrm{OD}_{600} 2.0-4.0\right)$ by centrifugation at $>13,000 \mathrm{rpm}$ (approximately 17,000 $\times g)$ in a table-top microcentrifuge for 1 minute at room temperature $\left(15^{\circ} \mathrm{C}\right.$ $25^{\circ} \mathrm{C}$ ). The medium was then removed by decanting and/or pipetting. Next, to ensure maximum DNA yield, $400 \mu \mathrm{l}$ ice cold Complete Lysis Solution (previously prepared and kept on ice at $<4^{\circ} \mathrm{C}$ ) was added to the pelleted bacterial cells. These were then mixed thoroughly by vortexing at the highest setting for 30 seconds until the pellet was completely resuspended. The following step was incubation at room temperature for 3 minutes. The lysate was then transferred to a Quicklyse spin column by decanting and/or pipetting. Spin columns were then centrifuged for 30 - 60 seconds at 13,000 rpm in a table-top microcentrifuge. Each Quicklyse spin column was washed by adding $400 \mu$ diluted Buffer QLW (previously prepared) and centrifugation for 30 - 60 seconds at 13,000 rpm. The flow-through was discarded. The Quicklyse spin columns were put back in the waste tubes and returned to the centrifuge for 1 minute at 13,000 rpm to dry the columns. The spin columns were transferred into clean collection tubes. Finally, to elute DNA, $50 \mu \mathrm{l}$ Buffer QLE was pipetted directly onto the center of the Quicklyse spin column and centrifugation for $30-60$ seconds at 13,000 rpm. The eluted DNA (aliquots of $50 \mu \mathrm{l}$ ) were kept in a freezer at $-86^{\circ} \mathrm{C}$ for PCR amplification the following day.

\subsection{Molecular Identification of Panton-Valentine Leukocidintoxin}

Plasmid DNA of isolates was amplified by polymerase chain reaction (PCR). The PCR reaction mixtures consisted of: 1) $12.5 \mu$ DreamTaq Green PCR Master Mix (ThermoScientific); 2) $0.25 \mu$ forward primer; 3) $0.25 \mu$ reverse primer (Inqaba Biotech, Pretoria, South Africa); 4) $1 \mu \mathrm{l}$ template DNA; and $11 \mu \mathrm{l}$ nuclease-free water to make up a total volume of $25 \mu \mathrm{l}$. Primers used to detect the 
luksgene were 5'-CAGGAGGTAATGGTTCATTT-3' (Forward) and 5'ATGTCCAGACATTTTACCTAA-3' (Reverse) previously used by [11], and those for the $l u k F$ gene were 5'-ATCCGAGAGACTATTTTGTGC-3' (Forward) and 5'-CATCAACCTTTTTCTCACTTAC-3' (Reverse) used by [12], yielding a 151 bp lukS DNA fragment and a 406 bp lukF DNA fragment, respectively [11] [12].

Mixtures were gently vortexed and briefly ( 3 seconds) centrifuged to ensure sufficient mixing of reagents before using an Applied Biosystems 2720 Thermal Cycler for amplification. The reaction mixtures were subjected to the following PCR cycling conditions: Cycle 1 (Initial denaturation): (1x) at $95^{\circ} \mathrm{C}$ for $300 \mathrm{sec}-$ onds (5 minutes); Cycle 2 (Denaturation, annealing, extension): $(35 \mathrm{x})$ at $95^{\circ} \mathrm{C}$ for 30 seconds ( 0.5 minutes), $58^{\circ} \mathrm{C}$ for 30 seconds ( 0.5 minutes), and $72^{\circ} \mathrm{C}$ for 60 seconds ( 1 minute); Cycle 3 (Final extension): (1x) at $72^{\circ} \mathrm{C}$ for 300 seconds (5 minutes).

Amplified PCR products were electrophoresed on a $2.5 \%(\mathrm{w} / \mathrm{v})$ agarose gel containing $12 \mu \mathrm{l} 0.5 \mu \mathrm{g} / \mathrm{ml}$ ethidium bromide and 1x TAE (Tris-acetate-EDTA) buffer at 90 volts for 50 minutes. Fifteen microliter PCR product was loaded into each well without loading gel, because the master mix already contains dyes. An O'GeneRuler 100 bp DNA ladder (ThermoScientific) was used. The gel was viewed using a Gel Doc ${ }^{\mathrm{TM}}$ EZ Imager and Image Lab ${ }^{\mathrm{TM}}$ version 5.0 (2013) from Bio-Rad Laboratories.

\section{Results and Discussion}

Plasmid DNA was isolated and amplified successfully from 22 multi-drug resistant MRSA nasal isolates and the $S$. aureus ATCC 33591 MRSA reference strain. The PCR results for PVL gene detection are shown in Figure 1. The results show that seven out of 22 multi-drug resistant MRSA nasal isolates from healthy school children had PVL toxin gene (s). As expected, the negative control MRSA strain ATCC 33591 tested negative for PVL toxin genes. From the seven isolates, three tested positive for both lukS and lukFgenes, yielding a 151bp lukS DNA fragment and a $406 \mathrm{bp}$ lukF DNA fragment, respectively. One isolate tested positive for only lukS, and three tested positive for only lukF. According to Brooks et al. (2013) [1] these S and F components of PVL toxin can kill human white blood cells by acting synergistically on the white cell membranes. Two of the isolates harbouring both lukS and lukF genes shared the same antibiotic resistance pattern and one of them could also produce enterotoxin A. One of the isolates with only lukF gene could produce enterotoxins B and C [10]. These toxin-producing isolates can be expected to be more virulent than those not producing any toxins [13] [14]. Such potentially virulent staphylococci might spread among the school children and wider Mariental community, especially in the absence of good hygiene practices like handwashing.

Govindan et al. (2015) [15] also detected PVL toxin in 10/17 non-multi-drug resistant MRSA nasal isolates from school children aged 5 - 16 years in Udupi 

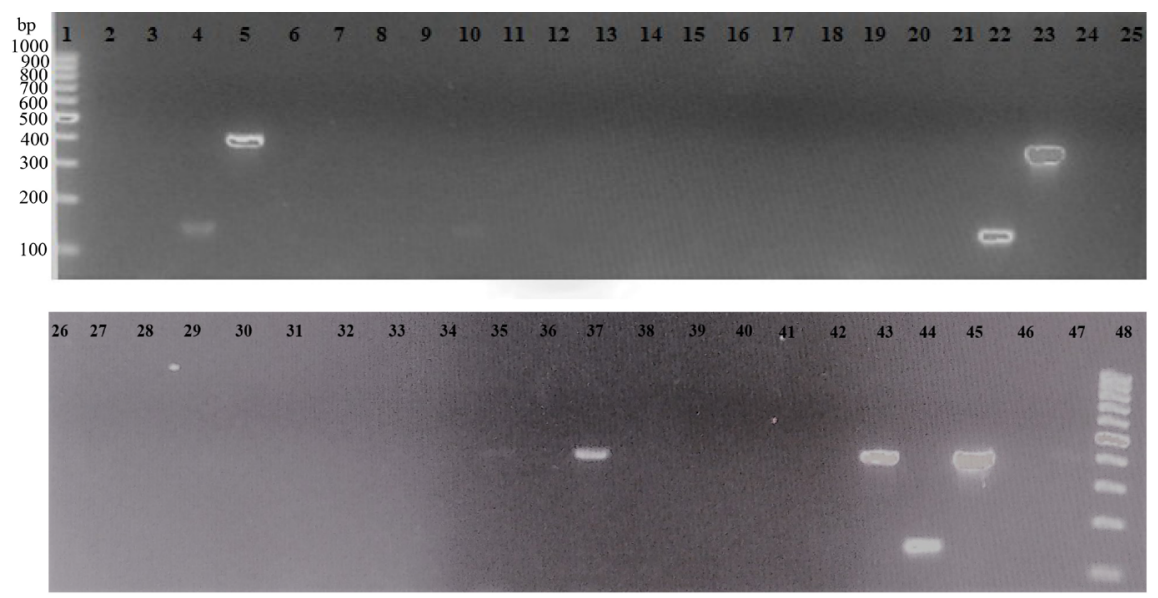

Lanes 1 \& 48: 100 bp DNA ladder; Lanes 2 \& 3: PVL-negative $S$. aureus ATCC33591 (Negative control)

\begin{tabular}{|c|c|c|c|c|c|}
\hline Isolate code & Lane number & Source & Antibiotic resistance pattern & Enterotoxins & PVL genes (s) detected \\
\hline MG2TSAB2 & $4 \& 5$ & $\begin{array}{l}13 \text {-year-old } \\
\text { boy }\end{array}$ & AP-GM-RP-FOX & Not tested & $\operatorname{lukS}(151 \mathrm{bp}) ; \operatorname{lukF}(406 \mathrm{bp})$ \\
\hline S37TSAPure & $10 \& 11$ & $\begin{array}{l}\text { 13-year-old } \\
\text { girl }\end{array}$ & AP-T-RP-FOX & Not tested & $\operatorname{lukS}(151 \mathrm{bp})$ \\
\hline M3TSAA & $22 \& 23$ & $\begin{array}{l}\text { 6-year-old } \\
\text { girl }\end{array}$ & AP-T-RP-FOX & Negative & lukS (151bp); lukF (406bp) \\
\hline DJ14S110PureA & $34 \& 35$ & $\begin{array}{l}\text { 12-year-old } \\
\text { girl }\end{array}$ & AP-T-RP-FOX & Negative & $\operatorname{lukF}(406 \mathrm{bp})$ \\
\hline $\begin{array}{l}\text { DDG54S110/ } \\
\text { TSAA }\end{array}$ & $36 \& 37$ & $\begin{array}{l}\text { 12-year-old } \\
\text { girl }\end{array}$ & AP-RP-E-FOX & Negative & $\operatorname{lukF}(406 \mathrm{bp})$ \\
\hline S1S110Pure & $42 \& 43$ & $\begin{array}{l}\text { 7-year-old } \\
\text { girl }\end{array}$ & AP-T-E-FOX & $\mathrm{B}, \mathrm{C}$ & $\operatorname{lukF}(406 \mathrm{bp})$ \\
\hline DJ25S110Pure & $44 \& 45$ & $\begin{array}{l}\text { 10-year-old } \\
\text { girl }\end{array}$ & AP-T-RP-FOX & A & $\operatorname{lukS}$ (151bp); lukF (406bp) \\
\hline
\end{tabular}

Figure 1. An ethidium bromide stained, agarose gel image of PCR amplified gene fragments showing PVL toxin genes detected in staphylococcal nasal isolates from healthy school children. According to our previously reported findings, antibiotic resistance patterns [18] for these isolates and their ability to produce enterotoxins [10] are also indicated.

Taluk, India. They suggested that PVL detection could be included in the routine diagnostic panel of MRSA infections. Rebollo-Pérez et al. (2011) [8] found that all five MRSA nasal isolates from healthy preschool children aged 2 - 6 years carried genes for PVL. After molecular typing, that study observed that three of these five PVL-positive isolates had features of healthcare-associated strains that may have spread from hospitals into the community. In a study by Huang et al. (2011) [16] 81/102 (79.4\%) CA-MRSA isolates from children in northern Taiwan were PVL gene-positive, and $92 \%$ of these children with CA-MRSA had skin and soft tissue infections. In contrast to our results, Alzoubi et al. (2014) [9] could not detect any PVL toxin in nasal CA-MRSA isolates from children aged 6 11 years in Al-Karak province in Jordan. Jenney et al. (2014) [17] also found that 20/299 (6.7\%) non-multi-drug resistant MRSA isolates from impetigo lesions of 14 school children aged 5 - 15 years were all PVL-negative.

\section{Conclusion}

Given that 7/22 multi-drug resistant MRSA nasal isolates from healthy school 
children in Mariental harbour PVL toxin gene(s), and that some of these isolates are enterotoxigenic, it is expected that these isolates may have increased virulence. Children should be educated on the importance of regular handwashing with soap and water to prevent the spread of potentially virulent staphylococci amongst them and the wider community. The outcome of this study warrants a larger study to be carried out to investigate PVL toxin and its associated infections in Staphylococcus from school children in Namibia.

\section{Limitations}

Due to limited reagents for molecular work, only 22 multi-drug resistant MRSA isolates could be screened for PVL toxin genes. Future studies should include screening of non-drug resistant $S$. aureus isolates and coagulase-negative staphylococci for the presence of PVL genes.

\section{Acknowledgements}

The authors acknowledge and thank the University of Namibia's Biomedical Research Laboratory, Biological Sciences Department where the work was carried out. We also acknowledge and thank the Southern African Biochemistry and Informatics for Natural Products (SABINA) and the Regional Initiative in Science and Education (RISE) for financial support. This work forms part of a larger Ph.D. study undertaken at the University of Namibia.

\section{Conflicts of Interest}

The authors declare no conflicts of interest regarding the publication of this paper.

\section{References}

[1] Brooks, G.F., Carroll, K.C., Butel, J.S., Morse, S.A. and Mietzner, T.A. (2013) Jawetz, Melnick \& Adelberg's Medical Microbiology. 26th Edition, McGraw-Hill, New York.

[2] Lowy, F.D. (2010) Staphylococcal Infections. In: Kasper, D. and Fauci, A., Eds., Harrison's Infectious Diseases, McGraw-Hill, New York, 386-399.

[3] Forbes, B.A., Sahm, D.F. and Weissfeld, A.S. (2007) Bailey and Scott's Diagnostic Microbiology. 12th Edition, Mosby, St. Louis.

[4] Pynnonen, M., Stephenson, R.E., Schwartz, K., Hernandez, M. and Boles, B.R. (2011) Hemoglobin Promotes Staphylococcus aureus Nasal Colonization. PLOS Pathogens, 7, e1002104. https://doi.org/10.1371/journal.ppat.1002104

[5] Prescott, L.M., Harley, J.P. and Klein, D.A. (2002) Microbiology. 5th Edition, McGraw-Hill, New York.

[6] Reid, M.J.A., Fischer, R.S.B., Mannathoko, N., Muthoga, C., McHugh, E., Essigmann, H., Brown, E.L. and Steenhoff, A.P. (2017) Prevalence of Staphylococcus aureus Nasal Carriage in Human Immunodefiency Virus-Infected and Uninfected Children in Botswana: Prevalence and Risk Factors. The American Journal of Tropical Medicine and Hygiene, 96, 795-801. https://doi.org/10.4269/ajtmh.16-0650

[7] Arali, S.M., Kulkarni, V., Manjula, N.G., Gaddad, S.M., Jayaraj, Y.M. and Shivan- 
navar, C.T. (2016) Prevalence and Antibiotic Susceptibility Profile of MRSA Isolated from the Anterior Nares of School Going Children in Gulbarga. International Journal of Medical Science and Public Health, 5, 620-626. https://doi.org/10.5455/ijmsph.2016.0805201592

[8] Rebollo-Pérez, J., Ordoñez-Tapia, C., Herazo-Herazo, C. and Reyes-Ramos, N. (2011) Nasal Carriage of Panton-Valentine Leukocidin-Positive Methicillin-Resistant Staphylococcus aureus in Healthy Preschool Children. Revista de Salud Pública, 13, 824-832. https://doi.org/10.1590/S0124-00642011000500011

[9] Alzoubi, H.M., Agel, A.A., Al-Sarayreh, S.A. and Al-Zayadneh, E. (2014) Methicillin-Resistant Staphylococcus aureus Nasal Carriage among Primary School-Aged Children from Jordan: Prevalence, Antibiotic Resistance and Molecular Characteristics. Journal of Egyptian Public Health Association, 9, 114-118.

https://doi.org/10.1097/01.EPX.0000454671.83406.e8

[10] Walter, S. (2018) Prevalence, Antibiotic Resistance Trends, Virulence and Effect of Some Medicinal Plants on Staphylococcus from School Children in the Mariental District, Namibia. PhD Dissertation, University of Namibia, Windhoek.

[11] Al-Talib, H., Yean, C.Y., Al-Khateeb, A., Hassan, H., Singh, K.-K.B., Al-Jashamy, K. and Ravichandran, M. (2009) Apentaplex PCR Assay for the Rapid Detection of Methicillin-Resistant Staphylococcus aureus and Panton-Valentine Leucocidin. BMC Microbiology, 9, 113. https://doi.org/10.1186/1471-2180-9-113

[12] Ribeiro, A., Dias, C., Silva-Carvalho, M.C., Berquó, L., Ferreira, F.A., Santos, R.N.S., Ferreira-Carvalho, B.T. and Figueredo, A.M. (2005) First Report of Infection with Community-Acquired Methicillin-Resistant Staphylococcus aureus in South America. Journal of Clinical Microbiology, 43, 1985-1988. https://doi.org/10.1128/JCM.43.4.1985-1988.2005

[13] Correa-Jiménez, O., Pinzón-Redondo, H. and Reyes, N. (2016) High Frequency of Panton-Valentine Leucocidin in Staphylococcus aureus Causing Pediatric Infections in the City of Cartagena-Colombia. Journal of Infection and Public Health, 9, 415-420. https://doi.org/10.1016/j.jiph.2015.10.017

[14] Sandersen, S. (2019) Panton Valentine Leukocidin Staphylococcus aureus Infection (PVL-SA): Patient Information. NHS Foundation Trust, Wigan.

[15] Govindan, S., Maroli, A.S., Ciraj, A.M. and Bairy, I. (2015) Molecular Epidemiology of Methicillin Resistant Staphylococcus aureus Colonizing the Anterior Nares of School Children of Udupi Taluk. Indian Journal of Medical Microbiology, 33, 129-133. https://doi.org/10.4103/0255-0857.150919

[16] Huang, Y.-C., Ho, C.-F., Chen, C.-J., Su, L.-H. and Lin, T.-Y. (2008) Comparative Molecular Analysis of Community-Associated and Healthcare-Associated Methicillin-Resistant Staphylococcus aureus Isolates from Children in Northern Taiwan. Clinical Microbiology and Infections, 14, 1167-1172.

https://doi.org/10.1111/j.1469-0691.2008.02115.x

[17] Jenney, A., Holt, D., Ritika, R., Southwell, P., Pravin, S., Buadromo, E., Carapetis, J., Tong, S. and Steer, A. (2014) The Clinical and Molecular Epidemiology of Staphylococcus aureus Infections in Fiji. BMC Infectious Diseases, 14, 160. https://doi.org/10.1186/1471-2334-14-160

[18] Walter, S. and Böck, R. (2020) Antibiotic Resistance Trends of Nasal Staphylococcal Isolates from Namibian School Children. Journal of Biosciences and Medicines, $\mathbf{8}$, 18-27. https://doi.org/10.4236/jbm.2020.83003 